\section{Klassisk anatomi i moderne drakt}
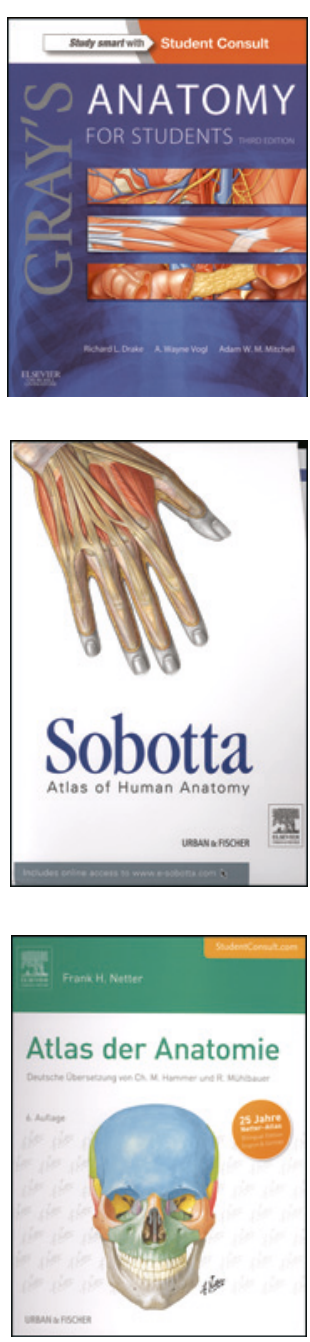

Frank H. Netter

\section{Atlas der Anatomie}

6. utg. 640 s, tab, ill. München: Elsevier GmbH, Urban \& Fischer Verlag, 2015

Pris EUR 90

ISBN 978-3-437-41605-7

Gode anatomikunnskaper er grunnsteinen i all klinisk virksomhet. Det er også faget der studentene kanskje for første gang opplever at de faktisk studerer medisin. Samtidig er det et fag med svært mange detaljer, som ikke alltid fremstår med logisk sammenheng. Anatomi huskes derfor ofte som et krevende puggefag. Desto viktigere er det da med læreverk som evner å forenkle og gi mening til kroppens strukturer og generelle oppbygning.

De tre anatomiverkene fra Elsevier, en lærebok og to atlas, utfyl- ler hverandre godt. Alle tre er bygd på klassikere innen anatomiske læreverk (Gray's, Sobotta og Netter er navn mange husker fra sin egen studietid). De er egnet for både medisinstudenter og for klinikere som ønsker å friske opp gamle anatomikunnskaper.

Gray's anatomi for students utkom første gang i 2005 og bygger på tidligere klassiske læreverk, men store deler er omarbeidet og nyskrevet med tanke på å tilfredsstille dagens ofte organorienterte studieløp. I mange av illustrasjonene legger man vekt på å få frem anatomiske prinsipper mer enn detaljer. Det gir god oversikt og letter innlæringen av stoffet. De åtte kapitlene dekker temaene kroppen, ryggen, thorax, abdomen, pelvis og perineum, underekstremiteten, overekstremiteten, hode og hals. Hvert kapittel inneholder først en prinsipell oversikt, så er det en mer detaljert gjennomgang av anatomien region for region, så en seksjon med overflateanatomi og til slutt en samling kliniske kasuistikker. En egen innholdsfortegnelse gir lett tilgang til det klinisk relevante stoffet. Boken er innbydende og lettlest og vil egne seg godt også for klinikere som ønsker et oppkvikkende gjensyn med gamle anatomikunnskaper. Den viktigste svakheten for norske lesere er at man konsekvent anvender engelsk nomenklatur, mens norsk praksis er å benytte latinsk.

Sobotta atlas of human anatomy, engelsk utgave med latinsk nomenklatur, er et trebinds anatomiatlas som nærmer seg lærebok i omfang. Den opprinnelige utgaven av atlaset utkom første gang i 1904, og den foreliggende versjonen er 15. utgave. De tre bindene omhandler generell anatomi med bevegelsesapparatet, interne organer og hode, hals og nevroanatomi. I tillegg til å fungere som et regulært atlas inneholder boken også mange figurtekster som forklarer spesielle forhold knyttet til de anatomiske strukturene. Den inneholder også en del klinske kommentarer, atskilt i separate bokser. Utgivelsen fremstår som et praktverk som man kan bruke som oppslagsverk også etter ferdig utdanning.

Atlas der Anatomie i tysk oversettelse med latinsk nomenklatur er 6. utgave av dette atlaset, som første gang ble utgitt av legen og tegneren Frank Netter (1906-91) etter hans ca. 50 år som medisinsk illustratør. Det inneholder stort sett fortsatt Netters originale tegninger, men er her og der supplert med oppdateringer og nye tegninger av Carlos Machado, også han utdannet lege. Dette er et rent atlas, uten figurtekster, men med enkelte røntgen- og CT-bilder, som dermed knytter anatomien nærmere det kliniske. En fyldig indeks gjør det lett å finne frem til bestemte strukturer i atlaset. Ekstra plansjer er tilgjengelig på nettet via bokens PIN-kode.

\section{Anne Spurkland}

Professor I, Avdeling for anatomi

Universitetet i Oslo 